\title{
6. STABLE ISOTOPE STUDY OF ANHYDRITE AND SULFIDE MINERALS AT THE TAG HYDROTHERMAL MOUND, MID-ATLANTIC RIDGE, 26$^{\circ} \mathbf{N}^{1}$
}

\author{
Hitoshi Chiba,${ }^{2}$ Noriaki Uchiyama, ${ }^{2}$ and Damon A.H. Teagle ${ }^{3}$
}

\begin{abstract}
The active mound of the Trans-Atlantic Geotraverse (TAG) hydrothermal system at the Mid-Atlantic ridge at $26^{\circ} \mathrm{N}$ was drilled during Ocean Drilling Program (ODP) Leg 158. One of the most important findings of the drilling is the discovery of an anhydrite-rich zone beneath the active mound. Stable isotope ratios of anhydrite and sulfide minerals are measured to investigate the formation conditions and mechanisms of the active mound and the anhydrite-rich zone. $\delta^{34} \mathrm{~S}$ values of sulfide minerals are heavier than those of other sediment-starved ridge hydrothermal systems. The heavy sulfide sulfur may be derived from the anhydrite in the reaction zone, which was precipitated in the waning stage of the former high-temperature activity of this system. Anhydrite $\delta^{18} \mathrm{O}$ and $\delta^{34} \mathrm{~S}$ are out of equilibrium with the hydrothermal fluid. Disequilibrium of the oxygen-isotope exchange reaction suggests a very short residence time of aqueous sulfate in a high-temperature environment. Anhydrite precipitation seems to have occurred instantaneously at the mixing interface where $\mathrm{Ca}^{2+}$ was supplied from the hydrothermal solution and $\mathrm{SO}_{4}{ }^{2-}$ from the seawater. Anhydrite ${ }^{87} \mathrm{Sr} /{ }^{86} \mathrm{Sr}$ values suggest the preheating of seawater sulfate before it enters the anhydrite formation zone. The chemical behavior of seawater upon heating and interaction with basalt indicate that the preheating of seawater takes place at the environment where basalt is absent. Seawater must invade from the surface of the mound into the anhydrite-rich zone.
\end{abstract}

\section{INTRODUCTION}

The Trans-Atlantic Geotraverse (TAG) hydrothermal field is located on the eastern side of the median valley of the Mid-Atlantic Ridge at $26^{\circ} 08^{\prime} \mathrm{N}$. Hydrothermal deposits have been found in a $5 \times 5$ $\mathrm{km}$ area, but the known high-temperature venting is restricted to an active mound, which is about $200 \mathrm{~m}$ in diameter and $50 \mathrm{~m}$ high. It is one of the largest hydrothermally active mounds so far discovered (Rona et al., 1986).

During ODP Leg 158, a series of holes was drilled at the active mound from September to November, 1994. One of the important discoveries of the leg is the abundance of anhydrite beneath the surface of the active mound (Humphris et al., 1995). Anhydrite/gypsum is common in some zones of Kuroko-type massive sulfide deposits in Japan. However, Cyprus-type massive sulfide deposits do not have massive anhydrite zones. The discovery of anhydrite beneath the active hydrothermal sulfide mound may provide important clues to investigate the formation mechanism of the massive sulfide deposit formed at mid-ocean ridge hydrothermal systems.

The purpose of this study is to investigate the origin of sulfide sulfur and the formation mechanism of the anhydrite-rich zone using sulfur- and oxygen-isotopic ratios of anhydrite and sulfide minerals.

\section{SAMPLES AND ANALYTICAL METHODS}

Samples are taken mainly from the TAG-1 area (Holes 158-957C, 957E, and 957G) from depths between 12.3 and 120.85 mbsf. All the lithologic units in the TAG-1 area (Humphris et al., 1995) were sampled. Three sulfide samples were also taken from the TAG-2 area (Holes $158-957 \mathrm{~B}$ and $957 \mathrm{H}$; 1.0 to $9.07 \mathrm{mbsf}$ ) to compare $\delta^{34} \mathrm{~S}$ values of sulfide minerals with samples from the TAG-1 area.

${ }^{1}$ Herzig, P.M., Humphris, S.E., Miller, D.J., and Zierenberg, R.A. (Eds.), 1998. Proc. ODP, Sci. Results, 158: College Station, TX (Ocean Drilling Program).

${ }^{2}$ Department of Earth and Planetary Sciences, Kyushu University 33, 6-10-1 Hakozaki, Fukuoka 812, Japan. hchiba@geo.kyushu-u.ac.jp

${ }^{3}$ Department of Geological Sciences, 2534 Little Building, University of Michigan, Ann Arbor, MI 48109-1063, U.S.A.
Samples for the oxygen- and sulfur-isotope analyses were handpicked from the specimens. Sulfide samples were washed with a dilute $\mathrm{HCl}$ solution to remove sulfate minerals, then oxidized to sulfate by reaction with concentrated nitric acid and $\mathrm{Br}_{2}$. After removing cations using cation-exchange resin, sulfate ion was quantitatively precipitated as $\mathrm{BaSO}_{4}$ by adding $\mathrm{BaCl}_{2}$ solution. Anhydrite samples were dissolved in dilute $\mathrm{HCl}$ solution. After removal of cations by the ion-exchange resin, $\mathrm{SO}_{4}{ }^{2-}$ ion in the solution was precipitated as $\mathrm{BaSO}_{4}$. Sulfur dioxide gas for the sulfur-isotope analysis was prepared by the $\mathrm{V}_{2} \mathrm{O}_{5}$ heating method (Yanagisawa and Sakai, 1983). Carbon dioxide gas for oxygen-isotope analysis was prepared by the graphite reduction method (Sakai and Krouse, 1971). The sulfur- and oxygen-isotope ratios were measured using VG Sira-10 and VG Prism mass spectrometer, respectively. Values of $\delta^{34} S$ and $\delta^{18} \mathrm{O}$ are reported relative to the CDT and SMOW scales, respectively. During measurements, OGS-1, which is seawater sulfate precipitated as $\mathrm{BaSO}_{4}$, was analyzed for comparison. Analytical errors for both oxygen- and sulfur-isotope ratios are lower than $\pm 0.1 \%$ o.

\section{RESULTS}

Sulfur-isotopic ratios of sulfide samples are shown in Table 1 and Figure 1. Values of $\delta^{34} \mathrm{~S}$ range from $6.50 \%$ o to $8.84 \%$. $\delta^{34} \mathrm{~S}$ values of sulfides in the TAG-2 area are within the same range as those in the TAG-1 area. No difference in $\delta^{34} \mathrm{~S}$ values was found between samples associated with anhydrite (above $58.9 \mathrm{mbsf}$ ) and samples not associated with anhydrite (120.9 mbsf), and there is no obvious trend in $\delta^{34} \mathrm{~S}$ of sulfide minerals with depth (Fig.1). The $\delta^{34} \mathrm{~S}$ values of sulfide minerals in the TAG active mound are significantly higher than those in other sediment-starved, ocean-floor hydrothermal systems (e.g., Shanks et al., 1995).

Sulfur- and oxygen-isotopic ratios of anhydrite are listed in Table 2 and are shown in Figure 1. $\delta^{34} \mathrm{~S}$ values of anhydrite range from $21.4 \%$ o to $22.8 \%$ o. There is no trend of $\delta^{34} \mathrm{~S}$ with depth. Most of them are heavier than the $\delta^{34} \mathrm{~S}$ of seawater sulfate, that is $20.99 \%$ (Rees et al., 1978). Anhydrite $\delta^{18} \mathrm{O}$ values are more widely scattered than $\delta^{34} \mathrm{~S}$ values, ranging from $6.5 \%$ o to $9.5 \%$. Most of them are lighter than $\delta^{18} \mathrm{O}$ of seawater sulfate $(9.1 \%$ o to $9.6 \%$; Kusakabe et al., 1990). Al-

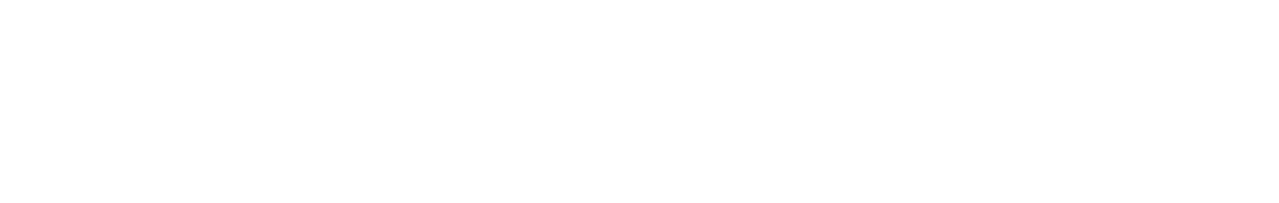


though they show large scatter in range, there is no obvious trend of $\delta^{18} \mathrm{O}$ with depth below seafloor (Fig.1).

\section{DISCUSSION}

\section{Source of Sulfide Sulfur}

The difference in $\delta^{34} \mathrm{~S}$ between sulfide and anhydrite is almost constant down to $48.5 \mathrm{mbsf}$ (Fig.1). This may indicate that the two minerals are formed at the same temperature regardless of the depth. However, high-temperature seawater-basalt interaction removes sulfate ion from the seawater-derived hydrothermal solution (e.g., Bischoff and Seyfried, 1978). The sulfate concentration of the TAG hydrothermal fluid discharged at the black smoker are almost zero (Gamo et al., 1996). Thus, it is not likely that sulfide and sulfate min-

Table 1. Sulfur isotopic ratios of sulfide minerals, Site 957.

\begin{tabular}{lcrc}
\hline \multicolumn{1}{c}{ Hole, core, section } & Mineral & $\begin{array}{r}\text { Depth } \\
\text { (mbsf) }\end{array}$ & $\begin{array}{c}\delta^{34} \mathrm{~S} \\
(\%)\end{array}$ \\
\hline TAG-1 area & & & \\
957F-1N-1 (Piece 10A) & py & 1.41 & 7.15 \\
957G-1N-1 (Piece 7) & py & 12.32 & 7.53 \\
957C-5N-1 (Piece 1) & py & 15.00 & 7.20 \\
957C-10N-1 (Piece 2) & py & 28.75 & 7.34 \\
957C-11N-2 (Piece 1B) & py & 32.19 & 6.98 \\
957C-12N-2 (Piece 11B) & py & 36.23 & 6.88 \\
957C-12N-3 (Piece 3) & py & 36.64 & 8.41 \\
957C-13N-2 (Piece 3A) & py & 38.71 & 6.59 \\
957C-14N-1 (Piece 6) & cp & 40.61 & 7.04 \\
957C-15N-2 (Piece 1E) & cp & 43.18 & 6.50 \\
957C-16N-2 (Piece 9D) & py & 48.50 & 8.28 \\
957E-5R-1 (Piece 7) & py & 58.92 & 8.84 \\
957E-18R-1 (Piece 3) & py & 120.85 & 8.08 \\
TAG-2 area & & & \\
957B-1R (Piece 1) & py + cp & 1.00 & 7.92 \\
957B-1R-2 (Piece 1) & py + cp & 1.03 & 7.73 \\
957H-1N-1 (Piece 9) & py & 9.07 & 8.37 \\
\hline
\end{tabular}

Note: py $=$ pyrite, $\mathrm{cp}=$ chalcopyrite. erals were precipitated simultaneously from the hydrothermal fluid alone. The constant apparent sulfur isotope fractionations between sulfide and anhydrite must be a coincidence because of the nearly constant $\delta^{34} S$ values of the sulfide and anhydrite.

The $\delta^{34} \mathrm{~S}$ of sulfide minerals at sediment-starved ridge hydrothermal systems typically range from $1 \%$ o to $7 \%$ (Shanks et al., 1995). Sulfide minerals at the TAG active mound are isotopically heavier than those at other sediment-starved systems (Table 1), including pyrite from below the anhydrite-rich zone (Sample 158-957E-18R-1, [Piece 3]). Thus, hydrogen sulfide supplied from the deep reaction zone is isotopically heavier than in other sediment-starved systems. The sulfur-isotopic ratio of MORB is $+0.3 \%$ $\pm 0.5 \%$ o (Sakai et al, 1984). Using the value for sulfur in basalt, the maximum $\delta^{34} \mathrm{~S}$ values theoretically modeled would be $4.5 \%$ oven when the seawater sulfate is reduced by ferrous iron in hydrothermal fluid during mixing of seawater and hydrothermal fluid at the seafloor (Janecky and Shanks, 1988). Pyrite $\delta^{34} S$ values in the TAG active mound exceed $8 \%$ o. Such a heavy sulfur-isotopic ratio requires the addition of sulfur from seawater sulfate. Reduction of aqueous sulfate and/or reduction of anhydrite must have occurred in the deep reaction zone of this system. High-temperature hydrothermal activity at the active TAG mound began about $20 \mathrm{ka}$, and, although it is active at present, venting may have been intermittent in the past (Lalou et al., 1993). This implies that the major fracture system focusing the hydrothermal discharge can be reactivated. When high-temperature activity declines, lowtemperature, seawater-derived fluid may eventually enter the reaction zone. If the temperature along the path from the recharge zone to the reaction zone is low enough, seawater sulfate can reach the reaction zone leading to anhydrite precipitation at depth in the reaction zone. If the high-temperature activity is reactivated, seawater-derived sulfate, in the form of anhydrite, is available as source of sulfide sulfur in addition to the basaltic sulfur (Janecky and Shanks, 1988). The sulfate sulfur can be reduced by the reaction with ferrous iron in basalt and would be incorporated into the hydrothermal fluid. This mechanism can explain the isotopically heavy sulfide in the seafloor
Figure 1. Depth profile of $\delta^{34} \mathrm{~S}$ and $\delta^{18} \mathrm{O}$ values for anhydrite and sulfide minerals from the TAG-1 and the TAG2 area, TAG active mound.

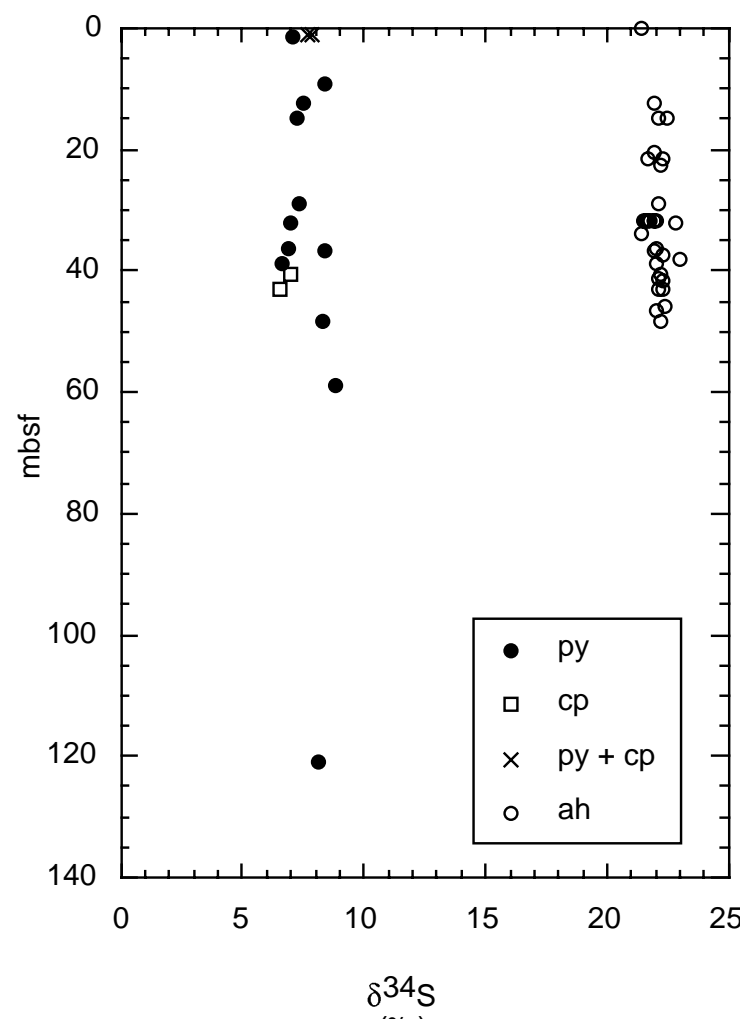

(\%)

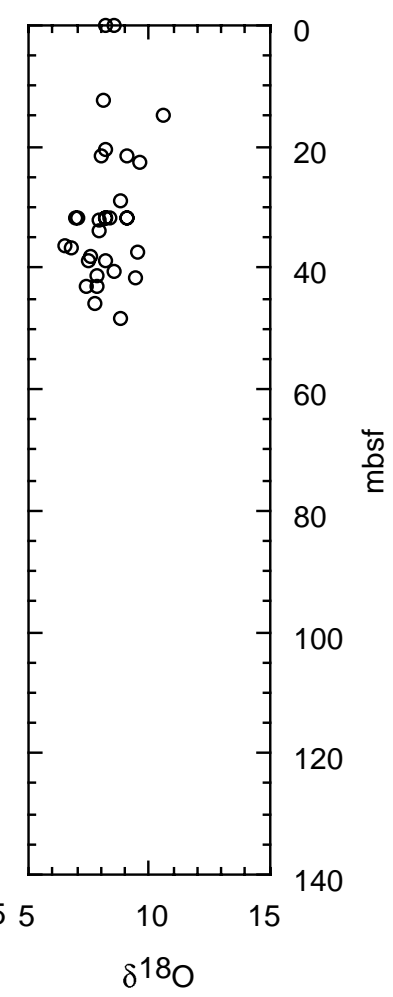

(\%०) 
Table 2. Sulfur- and oxygen-isotope ratios of anhydrite from the TAG-1 area, Site 957.

\begin{tabular}{lccc}
\hline \multicolumn{1}{c}{ Hole, core, section } & $\begin{array}{l}\text { Depth } \\
(\mathrm{mbsf})\end{array}$ & $\begin{array}{c}\delta^{34} \mathrm{~S} \\
(\%)\end{array}$ & $\begin{array}{c}\delta^{18} \mathrm{O} \\
(\% \mathrm{o})\end{array}$ \\
\hline 957G-1N-1 (Piece 7) & 12.3 & 21.9 & 8.1 \\
957C-5N-1 (Piece 1) & 15.0 & 22.1 & n.a. \\
957C-7N-1 (Piece 8B) & 20.3 & 21.9 & 8.2 \\
957G-3N-1 (Piece 4D) & 21.4 & 22.3 & 9.1 \\
957C-7N-2 (Piece 1H) & 21.7 & 21.7 & 8.0 \\
957C-7N-3 (Piece 3) & 22.5 & 22.2 & 9.6 \\
957C-10N-1 (Piece 2) & 28.8 & 22.1 & 8.8 \\
957C-11N-1 (Piece 3J, 109 cm) & 31.8 & 21.9 & 6.9 \\
957C-11N-1 (Piece 3J, 111 cm) & 31.8 & 22.0 & 8.4 \\
957C-11N-1 (Piece 3K, 125 cm) & 31.9 & 21.7 & 7.0 \\
957C-11N-1 (Piece 3K, 126 cm) & 31.9 & 21.6 & 8.2 \\
957C-11N-1 (Piece 3K, 129 cm) & 31.9 & 21.9 & 9.1 \\
957C-11N-1 (Piece 3K, 129 cm) & 31.9 & 21.5 & 8.2 \\
957C-11N-1 (Piece 3K, 129 cm) & 31.9 & 21.8 & 9.1 \\
957C-11N-2 (Piece 1B) & 32.2 & 22.8 & 7.9 \\
957C-11N-3 (Piece 5B) & 34.0 & 21.4 & 7.9 \\
957C-12N-2 (Piece 11B) & 36.2 & 22.0 & 6.5 \\
957C-12N-3 (Piece 3) & 36.6 & 21.9 & 6.8 \\
957E-2R-1 (Piece 6) & 37.3 & 22.3 & 9.5 \\
957C-13N-1 (piece 15) & 38.0 & 23.0 & 7.6 \\
957C-13N-2 (Piece 3A) & 38.7 & 22.0 & 7.5 \\
957C-13N-2 (Piece 3A) & 38.7 & 22.0 & 8.2 \\
957C-14N-1 (Piece 6) & 40.6 & 22.2 & 8.5 \\
957C-14N-2 (Piece 1B) & 41.1 & 22.1 & 7.8 \\
957E-3R-1 (Piece 3) & 41.8 & 22.3 & 9.4 \\
957C-15N-1 (Piece 11B) & 42.9 & 22.3 & 7.8 \\
957C-15N-2 (Piece 1E) & 43.2 & 22.1 & 7.4 \\
957C-15N-4 (Piece 2) & 45.9 & 22.4 & 7.7 \\
957C-16N-1 (Piece 7) & 46.7 & 22.0 & n.a. \\
957C-16N-2 (Piece 9D) & 48.5 & 22.2 & 8.8 \\
\hline
\end{tabular}

Note: n.a. $=$ not analyzed

hydrothermal systems that intermittently discharge high-temperature fluids.

\section{Oxygen and Sulfur Isotopic Ratio of Anhydrite}

The relationship between $\delta^{18} \mathrm{O}$ and $\delta^{34} \mathrm{~S}$ of anhydrite and seawater sulfate is shown in Figure 2. Both $\delta^{18} \mathrm{O}$ and $\delta^{34} \mathrm{~S}$ of anhydrite samples differ from seawater sulfate. Anhydrite $\delta^{34} \mathrm{~S}$ values are almost constant, but are $0.6 \%$ o to $2 \%$ o heavier than the $\delta^{34} S$ of seawater sulfate. Anhydrite $\delta^{18} \mathrm{O}$ values, however, are variable and are smaller than the $\delta^{18} \mathrm{O}$ of seawater sulfate.

The processes that can affect the isotopic composition of anhydrite are depicted schematically in Figure 3. Anhydrite inherits its oxygen- and sulfur-isotope ratio from the aqueous sulfate at the time of precipitation, but there is a small oxygen-isotope fractionation between aqueous sulfate and anhydrite $\left(0.1 \%\right.$ at $300^{\circ} \mathrm{C}$; Chiba et al., 1981). Once anhydrite precipitates, further isotope exchange reaction does not easily take place, because it must proceed through very slow diffusion in solid anhydrite. Variations shown on Figure 2 mainly reflect isotope-exchange reactions in the fluid, which occur before anhydrite precipitates. The sulfur-isotope ratio of aqueous sulfate can change through isotope-exchange with hydrogen sulfide, which is the major sulfur-bearing species in the hydrothermal fluid. The resulting $\delta^{34} \mathrm{~S}$ of the exchanged sulfate depends on the $\delta^{34} \mathrm{~S}$ of $\mathrm{H}_{2} \mathrm{~S}$, temperature, and the degree to which equilibrium is approached. If we assume that $\mathrm{H}_{2} \mathrm{~S}$ is in sulfur-isotope equilibrium of $7 \%$ o with pyrite, the sulfur-isotope exchange reaction between aqueous sulfate and $\mathrm{H}_{2} \mathrm{~S}$ makes $\delta^{34} \mathrm{~S}$ of aqueous sulfate lighter than that of seawater sulfate above $380^{\circ} \mathrm{C}$ and heavier below $380^{\circ} \mathrm{C}$ (Ohmoto and Lasaga, 1982; Kiyosu, 1973; Kajiwara and Krouse, 1971). Oxygen-isotope ratio of sulfate can also change through the isotope-exchange reaction between fluid and aqueous sulfate. Assuming that aqueous sulfate attains isotope equilibrium with the TAG hydrothermal fluid $\left(\delta^{18} \mathrm{O}=\right.$ $1.5 \%$; Shanks et al., 1995), the $\delta^{18} \mathrm{O}$ of precipitating anhydrite becomes higher than that of seawater sulfate below $230^{\circ} \mathrm{C}$ and smaller above $230^{\circ} \mathrm{C}$ (Chiba et al., 1981). Another process that could affect

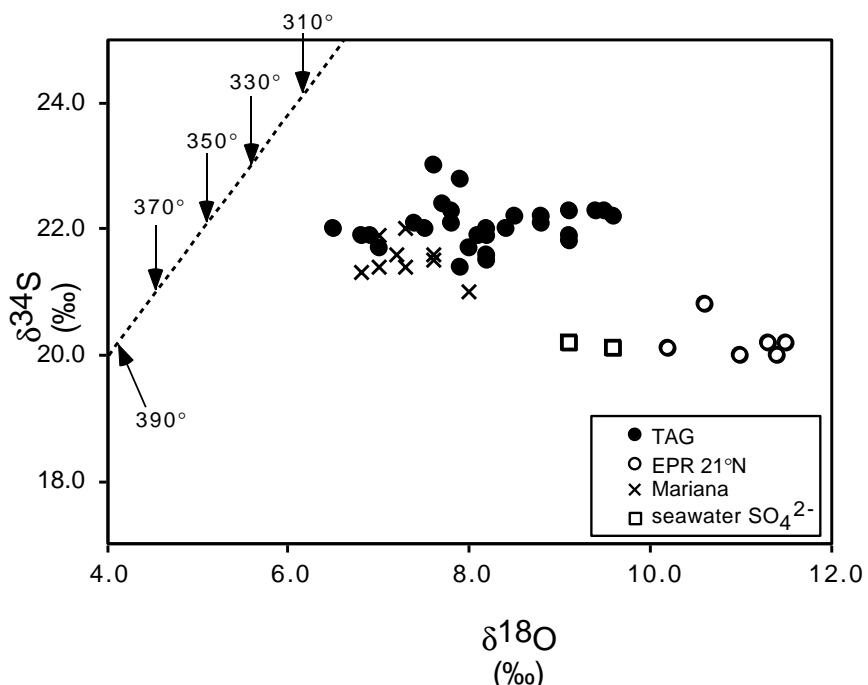

Figure 2. Relationship between $\delta^{18} \mathrm{O}$ and $\delta^{34} \mathrm{~S}$ of sulfate minerals from seafloor hydrothermal systems. Solid circles = anhydrite of TAG-1 area; open circles $=$ anhydrite of black smoker chimney at EPR $21^{\circ} \mathrm{N}$ (Kusakabe et al. 1982); X's = barite chimney at Mariana backarc basin (Kusakabe et al., 1990); open squares $=$ seawater $\mathrm{SO}_{4}{ }^{2-}$. Dashed line indicates the isotopeequilibrium condition of anhydrite with pyrite $\left(\delta^{34} \mathrm{~S}=7 \%\right.$ o $)$ and hydrothermal fluid $\left(\delta^{18} \mathrm{O}=1.5 \%\right.$ ) at various temperatures.

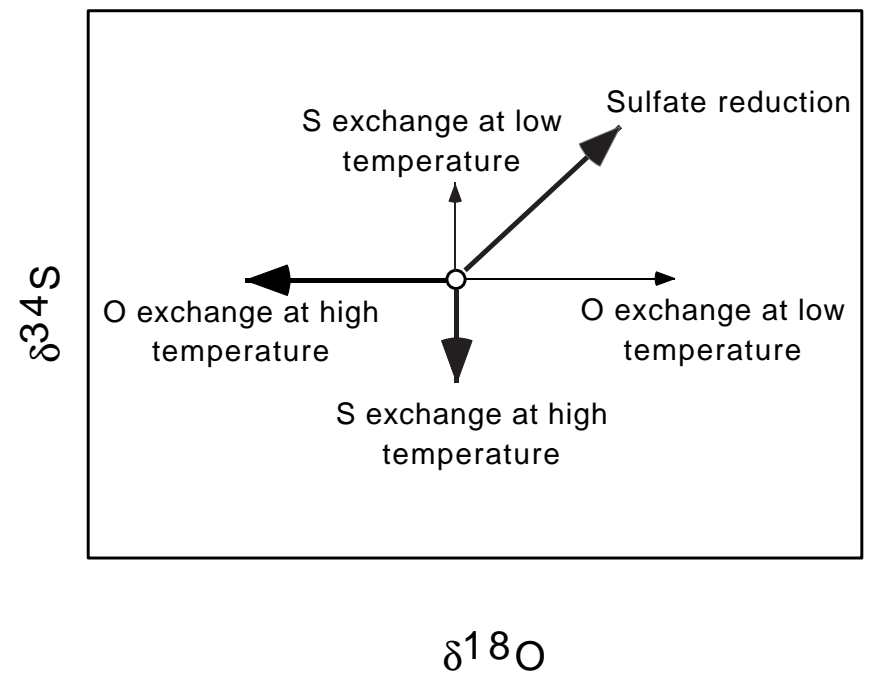

Figure 3. Processes that affect $\delta^{18} \mathrm{O}$ and $\delta^{34} \mathrm{~S}$ of anhydrite. Arrows indicate the direction of change in isotopic ratios.

both $\delta^{34} S$ and $\delta^{18} \mathrm{O}$ of aqueous sulfate is sulfate reduction. During sulfate reduction, the isotopically light molecules are preferentially reduced to sulfide, and the remaining sulfate becomes isotopically heavier than the original sulfate.

The dashed line on Figure 2 indicates equilibrium isotope fractionation among anhydrite, pyrite, and hydrothermal fluid as a function of temperature, given the assumptions above. From this figure, sulfur-isotope ratios of anhydrite seem to be in equilibrium with TAG hydrothermal solution at around $350^{\circ} \mathrm{C}$, which is slightly lower than the temperature estimated from fluid inclusions, around $360^{\circ} \mathrm{C}$ (Uchiyama, unpubl. data). However, the calculated equilibrium oxygen-isotope temperatures between sulfate and hydrothermal fluid are all less than $305^{\circ} \mathrm{C}$. Consequently, oxygen-isotope ratios of anhydrite 
are far from equilibrium at temperatures of anhydrite precipitation indicated by fluid inclusions, although $\mathrm{SO}_{4}{ }^{2-}$ could have exchanged its oxygen isotopes with hydrothermal fluid to various degrees at temperatures higher than $230^{\circ} \mathrm{C}$. Equilibrium between sulfur-isotopes would not be expected if the oxygen-isotopes are not in equilibrium. Oxygen-isotope exchange reactions between sulfate ion and water must be faster than sulfur-isotope exchange between sulfate ion and $\mathrm{H}_{2} \mathrm{~S}$, because the sulfur atom in the sulfate ion is surrounded by four oxygen atoms, so more bonds must be broken, which is confirmed by experimental works (Chiba and Sakai, 1985; Ohmoto and Lasaga, 1982). Therefore, high $\delta^{34} \mathrm{~S}$ values of anhydrite is not interpreted to be a result of equilibrium exchange with $\mathrm{H}_{2} \mathrm{~S}$ in the TAG fluid. The slight increase in $\delta^{34} S$ of anhydrite compared with seawater sulfate is probably caused by partial reduction, about $10 \%$, of seawater sulfate by ferrous iron in the hydrothermal fluid during mixing of seawater and hydrothermal fluid in the anhydrite precipitation zone.

The oxygen-isotope exchange rates between aqueous sulfate and water were experimentally determined at various temperatures (Chiba and Sakai, 1985). The half-reaction time depends on the temperature, $\mathrm{pH}$ of the solution, and total sulfur concentration. Extrapolation of their results to $360^{\circ} \mathrm{C}$ suggests that the half-reaction time of oxygen-isotope exchange between aqueous sulfate and water is less than a few minutes at in situ $\mathrm{pH}$ as calculated by Tivey et al. (1995). The temperature-pH-time path of $\mathrm{SO}_{4}{ }^{2-}$-bearing fluid that is responsible for precipitation of anhydrite in the active mound is not clear at present. Therefore, it is not possible to estimate the residence time of the fluid responsible for anhydrite formation in the mound. The failure to attain oxygen isotope equilibrium, however, does suggest that aqueous sulfate must have precipitated as anhydrite extremely rapidly within anhydrite-rich zone. It also may suggest that the flow rate of the $\mathrm{SO}_{4}{ }^{2-}$-bearing fluid into the subsurface of the mound is very rapid. Samples of disseminated anhydrite (Samples 158-957C-12N2, [Piece 1B] and 158-957C-12N-3, [Piece 3]) and from narrow veins (Samples 158-957C-13N-1, [Piece 15], 158-957C-13N-2, [Piece $3 \mathrm{~A}$ ], $158-957 \mathrm{C}-15 \mathrm{~N}-2$, [Piece 1E], and 158-957C-15N-4, [Piece 2]) tend to have lower $\delta^{18} \mathrm{O}$ values. It may indicate that the flow rate of $\mathrm{SO}_{4}{ }^{2-}$-bearing fluid slowed at the end of the flow path, allowing $\mathrm{SO}_{4}{ }^{2-}$ to approach oxygen isotopic equilibrium.

Five anhydrite samples were taken for isotope analyses from a single piece of core (Sample 158-957C-11N-1, [Piece 3K]) and their isotopic ratios are listed in Table 2. The range of $\delta^{34} \mathrm{~S}$ is from $21.6 \%$ to $21.9 \%$, which only slightly exceeds the reproducibility of the measurements. Values of $\delta^{18} \mathrm{O}$, however, vary from $7.0 \%$ to $9.1 \%$ within the 5-cm-long piece. This sample contains several generations of veins. The wide range of $\delta^{18} \mathrm{O}$ values of sulfate indicates that the formation conditions vary for individual veins.

\section{Flow Path of Seawater into the Mound}

Ca concentration of the TAG hydrothermal fluid $(26 \mathrm{mmol}$; Champbell et al., 1988) is higher than that of seawater (11 mmol) because of seawater-basalt interaction (Bischoff and Dickson, 1975), but sulfate ion is highly depleted (Gamo et al., 1996). To precipitate anhydrite beneath the subsurface of the mound, $\mathrm{SO}_{4}{ }^{2-}$-bearing solution (i.e., seawater) must invade from beneath the mound. Sr-isotopic ratios of anhydrite samples of the anhydrite-rich zone were measured by Teagle et al. (Ch. 11, this volume). Six sulfate samples, including one collected at the surface of the active mound by the Japanese submersible Shinkai 6500 were analyzed for their ${ }^{87} \mathrm{Sr} /{ }^{86} \mathrm{Sr}$ and ${ }^{18} \mathrm{O} /{ }^{16} \mathrm{O}$ ratios. The measured ${ }^{87} \mathrm{Sr} /{ }^{86} \mathrm{Sr}$ values $(0.70633$ to 0.70731$)$ are between the ${ }^{87} \mathrm{Sr} /{ }^{86} \mathrm{Sr}$ of seawater (0.709), TAG hydrothermal solution (0.704) (Gamo et al., 1996), and Mid-Atlantic Ridge basalt (0.7024 to 0.7026 ) (Hamelin et al., 1984; White and Schilling, 1978). ${ }^{87} \mathrm{Sr} /{ }^{86} \mathrm{Sr}$ values vary even within a 5 -cm-long piece of core, similar to $\delta^{18} \mathrm{O}$ values. If we assume that anhydrite formed by adiabatic mixing of ambient seawater $\left(2{ }^{\circ} \mathrm{C},{ }^{87} \mathrm{Sr} /{ }^{86} \mathrm{Sr}=0.709\right)$ and the hydrothermal solution $\left(360^{\circ} \mathrm{C},{ }^{87} \mathrm{Sr} /{ }^{86} \mathrm{Sr}=0.704\right)$, temperatures of the mixed solution can be calculated from the ${ }^{87} \mathrm{Sr} /{ }^{86} \mathrm{Sr}$ mass balance (Table 3 ). The con- tribution of seawater $\mathrm{Sr}$ to the anhydrite samples are from $31 \%$ to $49 \%$, giving calculated temperatures of $131^{\circ}$ to $204^{\circ} \mathrm{C}$. The calculated temperatures are much lower than the temperature estimated from fluid inclusions and $\delta^{18} \mathrm{O}$ values of anhydrite samples. The low temperatures estimated assuming adiabatic mixing suggest that the assumption is not valid. To account for higher estimated formation temperature of anhydrite by other methods, seawater that mixes with hydrothermal fluid must be heated prior to mixing, because mixing of hydrothermal fluid and $\mathrm{SO}_{4}{ }^{2-}$-bearing solution of seawater-origin causes anhydrite precipitation immediately. Table 3 shows that anhydrites precipitated under higher contribution of hydrothermal fluid, ones with low ${ }^{87} \mathrm{Sr} /{ }^{86} \mathrm{Sr}$ ratios, have low $\delta^{18} \mathrm{O}$ values (i.e., higher oxygen-isotope temperature), and that the temperatures calculated by oxygen-isotopes are about $100^{\circ} \mathrm{C}$ higher than the temperatures estimated by strontium-isotopes. Although $\delta^{18} \mathrm{O}$ of anhydrite is not in oxygen-isotope equilibrium with fluid from which anhydrite was precipitated, low $\delta^{18} \mathrm{O}$ of anhydrite indicates that $\mathrm{SO}_{4}{ }^{2-}$ partially exchanged its oxygen-isotopes with seawater before anhydrite precipitation. The progress of oxygen-isotope exchange-reaction is a function of temperature and duration of reaction: higher temperature increases the reaction rate and longer time enables the reaction to approach equilibrium. The tendency of anhydrite that has a low $\delta^{18} \mathrm{O}$ value to have a higher contribution of hydrothermal fluid suggests that seawater that invaded close to the main stream of hydrothermal fluid was heated at higher temperature and/or for a longer time compared to seawater that precipitated anhydrite with lower contribution of hydrothermal fluid.

Seawater begins to precipitate anhydrite when it is heated above $150^{\circ} \mathrm{C}$ (Bischoff and Dickson, 1975). If seawater is heated above $250^{\circ} \mathrm{C}$, magnesium hydroxyl sulfate hydroxide also begins to precipitate (Bischoff and Seyfried, 1978). Although the sulfate concentration in the seawater continues to decrease upon further heating, onethird of seawater sulfate remains in the heated seawater, even if it is heated to $350^{\circ} \mathrm{C}$ because there is insufficient $\mathrm{Ca}+\mathrm{Mg}$ to remove all sulfate from solution. If the seawater reacts with fresh basalt above $70^{\circ} \mathrm{C}, \mathrm{Mg}$ is removed from the seawater to form alteration minerals, and $\mathrm{Ca}$ is leached from basalt (Mottl, 1983). Thus, basalt-seawater interaction above $150^{\circ} \mathrm{C}$ forces all sulfate ions to precipitate as anhydrite. To form an anhydrite-rich zone beneath the active mound, seawater must flow into the anhydrite-forming zone without reacting with enough basalt to remove all sulfate through anhydrite precipitation. The feeder zone of the hydrothermal fluid beneath the TAG active mound appears to be narrow and restricted to the center part of the mound (Humphris et al., 1995). Also, basalt at the periphery of the mound is relatively unaltered. Therefore, the flow path of seawater into the anhydrite-formation zone is not likely to include significant flow through fresh basalt at temperature in excess of $150^{\circ} \mathrm{C}$. The heat-flow measurements on the active mound suggest that there is a seawater recharge zone at the western part of the mound (Becker and Von Herzen, 1996). If the seawater flows from the mound itself, it interacts mainly with low-Ca assemblages of sulfide and silica minerals

Table 3. Oxygen- and strontium-isotope ratios of anhydrite samples from the TAG-1 area, Site 957.

\begin{tabular}{lrrrrr}
\hline \multicolumn{1}{c}{ Hole, core, section } & $\begin{array}{c}\text { Depth } \\
(\mathrm{mbsf})\end{array}$ & $\begin{array}{c}\delta^{18} \mathrm{O} \\
(\% \circ)\end{array}$ & $\begin{array}{c}\mathrm{O} \\
\text { temperature } \\
\left({ }^{\circ} \mathrm{C}\right) *\end{array}$ & ${ }^{87} \mathrm{Sr} /{ }^{86} \mathrm{Sr}$ & $\begin{array}{c}\mathrm{Sr} \\
\text { temperature } \\
\left({ }^{\circ} \mathrm{C}\right) \dagger\end{array}$ \\
\hline 216R-3** & 0.0 & 8.5 & 252 & 0.707038 & 153 \\
957C-7N-1 (Piece 8B) & 20.3 & 8.2 & 258 & 0.707079 & 146 \\
957C-11N-1 (Piece 3K, 129 cm) & 31.9 & 9.1 & 239 & 0.707310 & 131 \\
957C-11N-1 (Piece 3K, 126 cm) & 31.9 & 8.2 & 258 & 0.706711 & 175 \\
957C-11N-1 (Piece 3K, 125 cm) & 31.9 & 7.0 & 289 & 0.706329 & 204 \\
957C-14N-2 (Piece 1B) & 41.1 & 7.8 & 268 & 0.706630 & 182 \\
957C-16N-2 (Piece 9D) & 48.5 & 8.8 & 245 & 0.706863 & 168 \\
\hline
\end{tabular}

Notes: $*=\mathrm{O}$ temperature is the oxygen-isotope equilibrium temperature between anhydrite and water $(1.5 \%) . \dagger=\mathrm{Sr}$ temperature is calculated assuming adiabatic mixing of seawater $\left(2^{\circ} \mathrm{C}\right)$ and hydrothermal fluid $\left(360^{\circ} \mathrm{C}\right)$. ** $=$ anhydrite collected at the surface of the mound by the submersible Shinkai 6500 . 
in the mound and does not interact with any fresh basalt. Thus, the heating of seawater in the mound is almost identical to the simple heating experiments. Such a flow path is favorable to the formation of the anhydrite-rich zone beneath the mound where this heated seawater mixed with hydrothermal fluid. Small amounts of sulfate may be reduced to produce slightly heavy $\delta^{34} S$ values of aqueous sulfate by the reaction with pyrite in the mound and/or ferrous iron in the hydrothermal fluid.

The flow paths of seawater and hydrothermal fluid are schematically shown in Figure 4. Seawater invades from the mound into the anhydrite-rich zone. Along this flow path, seawater is heated to some extent. When the heated seawater enters the anhydrite-rich zone and meets the hydrothermal fluid from the reaction zone, anhydrite precipitates at the mixing zone using $\mathrm{Ca}^{2+}$ from the hydrothermal fluid and $\mathrm{SO}_{4}{ }^{2-}$ from the seawater. Strontium-isotope ratios of the anhydrite provide a measure of the relative abundance of seawater and hydrothermal fluid. The precipitation must be very rapid, because $\delta^{18} \mathrm{O}$ of anhydrite is out of equilibrium with hydrothermal fluid or seawater at the temperature estimated by the fluid inclusions. This suggests that the flow rate of the seawater into the anhydrite-formation zone may be rapid, and that anhydrite precipitation probably takes place at the mixing interface between the two solutions.

\section{CONCLUSION}

Measurements of stable isotope ratios of sulfide minerals and anhydrite, mainly from the TAG-1 area of the active mound, together with the trapping temperatures of fluid inclusions, provide insights concerning the origin of sulfide sulfur, the mechanism of anhydrite precipitation beneath the mound, and the flow path of seawater into the anhydrite-rich zone.

1. Sulfide mineral $\delta^{34} \mathrm{~S}$ values are heavier than those of other sediment-starved ridge hydrothermal systems. The heavy $\delta^{34} S$ values indicate incorporation of sulfur of seawater sulfate origin. It may be derived from reduction of anhydrite in the reaction zone, which was precipitated during the waning stage of a former high-temperature discharge phase of this system.

2. Sampled anhydrite $\delta^{18} \mathrm{O}$ and $\delta^{34} \mathrm{~S}$ values are out of equilibrium with the hydrothermal fluid. Disequilibrium of oxygen-isotopes suggests a short residence time of aqueous sulfate in the high-temperature environment. Anhydrite precipitation occurred instantaneously at the mixing interface where $\mathrm{Ca}^{2+}$ was supplied predominantly from the hydrothermal solution and $\mathrm{SO}_{4}^{2-}$ from heated seawater.

3. Anhydrite ${ }^{87} \mathrm{Sr} /{ }^{86} \mathrm{Sr}$ values suggest contribution of hydrothermal fluid to anhydrite formation. An adiabatic mixing model using ${ }^{87} \mathrm{Sr} /{ }^{86} \mathrm{Sr}$ yields lower temperatures compared to temperatures estimated by oxygen-isotopes and fluid inclusions. Failure of the adiabatic mixing model indicates that seawater was heated before anhydrite precipitation. The chemical behavior of seawater upon heating and during interaction with basalt indicates that the preheating of seawater takes place in an environment where reactive basalt at high temperature is absent. Seawater must invade from the surface of the mound into the anhydrite-rich zone.

\section{ACKNOWLEDGMENTS}

All the stable isotope analyses were done at the Institute for the Study of the Earth's Interior (ISEI), Okayama University. HC and NU wish to thank Professor M. Kusakabe and Ms. T. Nogi of ISEI for their help in stable isotope analyses. This work benefited from reviews by M. Kusakabe, D. Stake, and R.A. Zierenberg. This work is partly supported by grant-in-aid for Scientific Research (No.

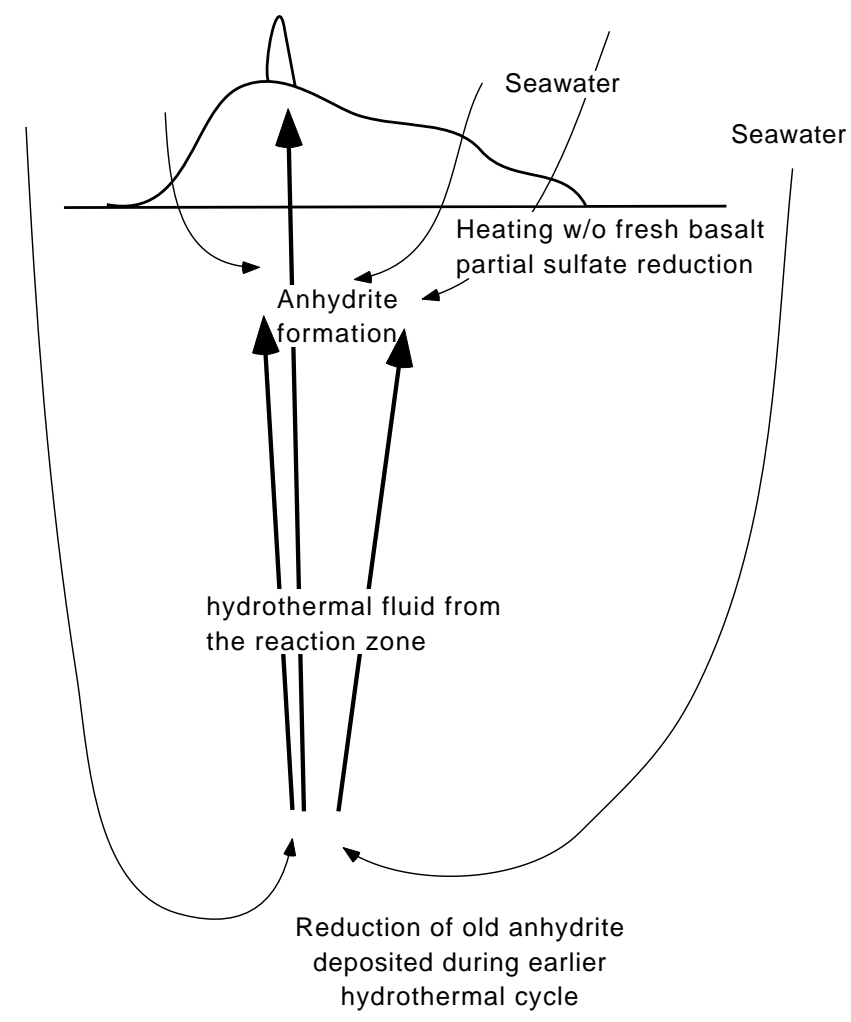

Figure 4. Diagram of flow paths of seawater and hydrothermal fluid in the TAG active mound. Hydrothermal fluid flow is focused above the reaction zone. It is postulated that anhydrite precipitated in the reaction zone during an earlier phase of low-temperature hydrothermal circulation and is now available for high-temperature sulfate reduction reactions. Seawater that enters through the surface of the mound is heated without reaction with basalt. Anhydrite is precipitated where the heated seawater and the hydrothermal fluid mix.

06044051) from the Ministry of Education, Science, Sports and Culture, Japan.

\section{REFERENCES}

Becker, K., and Von Herzen, R.P., 1996. Pre-drilling observations of conductive heat flow at the TAG active mound using Alvin. In Humphris, S.E., Herzig, P.M., Miller, D.J., et al., Proc. ODP, Init. Repts., 158: College Station, TX (Ocean Drilling Program), 23-29.

Bischoff, J.L., and Dickson, F.W., 1975. Seawater-basalt interaction at $200^{\circ} \mathrm{C}$ and 500 bars: implications for origin of seafloor heavy metal deposits and regulation of seawater chemistry. Earth Planet. Sci. Lett., 25:385-397.

Bischoff, J.L., and Seyfried, W.E., 1978. Hydrothermal chemistry of seawater from $25^{\circ} \mathrm{C}$ to $350^{\circ} \mathrm{C}$. Am. J. Sci., 278:838-860.

Champbell, A.C., Palmer, M.R., Klinkhammer, G.P. Bowers, T.S., Edmond, J.M., Lawrence, J.R., Casey, J.F., Thompson, G., Humphris, S., Rona, P., and Karson, J.A., 1988. Chemistry of hot springs on the Mid-Atlantic Ridge. Nature, 335:514-519.

Chiba, H., Kusakabe, M., Matsuo, S., Hirano, S., and Somiya, S., 1981. Oxygen isotope fractionation factors between anhydrite and water from 100 to $550^{\circ} \mathrm{C}$. Earth Planet. Sci. Lett., 53:55-62.

Chiba, H., and Sakai, H., 1985. Oxygen isotope exchange rate between dissolved sulfate and water at hydrothermal temperatures. Geochim. Cosmochim. Acta, 49:993-1000.

Gamo, T., Chiba, H., Masuda, H., Edmonds, H.N., Fujioka, K., Kodama, Y., Nanba, H., and Sano, Y., 1996. Chemical characteristics of hydrothermal fluids from the TAG mound of the mid-Atlantic Ridge in August 1994: implications for spatial and temporal variability of hydrothermal activity. Geophys. Res. Lett., 23:2483-3486.

Hamelin, B., Dupré, B., and Allègre, C.J., 1984. Lead-strontium isotopic variations along the East Pacific Rise and the Mid-Atlantic Ridge: a comparative study. Earth Planet. Sci. Lett., 67:340-350. 
Humphris, S.E., Herzig, P.M., Miller, D.J., Alt, J.C., Becker, K., Brown, D., Brügmann, G., Chiba, H., Fouquet, Y., Gemmell, J.B., Guerin, G., Hannington, M.D., Holm, N.G., Honnorez, J.J., Itturino, G.J., Knott, R., Ludwig, R., Nakamura, K., Petersen, S., Reysenbach, A.-L., Rona, P.A., Smith, S., Sturz, A.A., Tivey, M.K., and Zhao, X., 1995. The internal structure of an active sea-floor massive sulphide deposit. Nature, 377:713-716.

Janecky, D.R., and Shanks, W.C., III, 1988. Computational modeling of chemical and sulfur isotopic reaction processes in seafloor hydrothermal systems: chimneys, massive sulfides, and subjacent alteration zones. Can. Mineral., 26:805-825.

Kajiwara, Y., and Krouse, H.R., 1971. Sulfur isotope partitioning in metallic sulfide systems. Can. J. Earth Sci., 8:1397-1408.

Kiyosu, Y., 1973. Sulfur isotope fractionation among sphalerite, galena and sulfide ions. Geochem. J., 7:191-199.

Kusakabe, M., Chiba, H., and Ohmoto, H., 1982. Stable isotopes and fluid inclusions study of anhydrite from the East Pacific Rise at $21^{\circ} \mathrm{N}$. Geochem. J., 16:89-95.

Kusakabe, M., Mayeda, S., and Nakamura, E., 1990. S, O and Sr isotope systematics of active vent materials from the Mariana backarc basin spreading axis at $18^{\circ}$ N. Earth Planet. Sci. Lett., 100:275-282.

Lalou, C., Reyss, J.L., Brichet, E., Arnold, M., Thompson, G., Fouquet, Y., and Rona, P.A., 1993. New age data for Mid-Atlantic Ridge hydrothermal sites: TAG and Snakepit geochronology revisited. J. Geophys. Res., 98:9705-9713.

Mottl, M.J., 1983. Hydrothermal processes at seafloor spreading centers: application of basalt-seawater experimental results. In Rona, P.A., et al. (Eds.), Hydrothermal Processes at Seafloor Spreading Centers, New York (Plenum), 199-224.

Ohmoto, H., and Lasaga, A.C., 1982. Kinetics of reactions between aqueous sulfates and sulfides in hydrothermal systems. Geochim. Cosmochim. Acta, 46:1727-1745.

Rees, C.W., Jenkins, W.J., and Monster, J., 1978. The sulphur isotope geochemistry of ocean water sulphate. Geochim. Cosmochim. Acta, 42:377-382.
Rona, P.A., Klinkhammer, G., Nelson, T.A., Trefry, J.H., and Elderfield, H., 1986. Black smokers, massive sulfides and vent biota on the MidAtlantic Ridge. Nature, 321:33-37.

Sakai, H., Des Marais, D.J., Ueda, A., and Moore, J.G., 1984. Concentrations and isotope ratios of carbon, nitrogen and sulfur in ocean-floor basalts. Geochim. Cosmochim. Acta, 48:2433-2441.

Sakai, H., and Krouse, H.R., 1971. Elimination of memory effects in ${ }^{18} \mathrm{O} /{ }^{16} \mathrm{O}$ determination in sulphates. Earth Planet. Sci. Lett., 11:369-373.

Shanks, W.C., III., Böhlke, J.K., Seal, R.R., II, 1995. Stable isotopes in midocean ridge hydrothermal systems: interactions between fluids, minerals, and organisms. In Humphris, S.E., Zierenberg, R.A., Mullineaux, L.S., Thompson, R.E. (Eds.), Seafloor Hydrothermal Systems: Physical, Chemical, Biological, and Geological Interactions. Geophys. Monogr., 91:194-221.

Tivey, M.K., Humphris, S.E., and Thompson, G., 1995. Deducing patterns of fluid flow and mixing within the TAG active hydrothermal mound using mineralogical and geochemical data. J. Geophys. Res., 100:12,52712,555 .

White, W.M., and Schilling, J-G., 1978. The nature and origin of geochemical variation in Mid-Atlantic Ridge basalts from the central north Atlantic. Geochim. Cosmochim. Acta, 42:1501-1516.

Yanagisawa, F., and Sakai, H., 1983. Thermal decomposition of barium sulfate-vanadium pentoxide-silica glass mixtures for preparation of sulfur dioxide in sulfur isotope ratio measurements. Anal. Chem., 55:985-987.

Date of initial receipt: 3 June 1996

Date of acceptance: 14 February 1997

Ms 158SR-207 